\title{
PROPERTIES OF VANADIUM-BASE ALLOYS IRRADIATED IN THE DYNAMIC HELIUM CHARGING EXPERIMENT*
}

by

H. M. Chung, B. A. Loomis, and D. L. Smith

Argonne National Laboratory

Argonne, Illinois 60439, U.S.A.

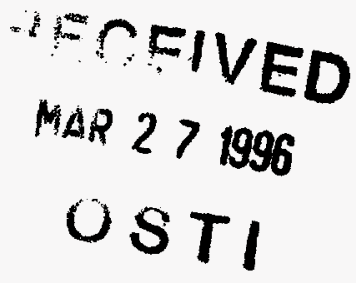

The submitted manuscript has been authored

by a contractor of the U.S. Government under

contract No. W-31-109-ENG-38. Accordingly,

the U.S. Government retains a nonexclusive,

royalty-free license to publish or reproduce the

published form of this contribution, or allow

others to do so, for U.S. Government purposes.

February 1996

Presented at the Seventh International Conference on Fusion Reactor Materials, September 25-29, 1995, Obninsk, Russia, and to be published in Journal of Nuclear Materials.

*Work supported by the U.S. Department of Energy, Office of Fusion Energy Research, under Contract W-31-109-Eng-38. 


\section{DISCLAMMER}

Portions of this document may be illegible in electronic image products. Images are produced from the best available original document. 


\title{
PROPERTIES OF VANADIUM-BASE ALLOYS IRRADIATED IN THE DYNAMIC HELIUM CHARGING EXPERIMENT
}

\author{
H. M. Chung, B. A. Loomis, and D. L. Smith \\ Argonne National Laboratory \\ Argonne, Illinois 60439, U.S.A.
}

\begin{abstract}
One property of vanadium-base alloys that is not well understood in terms of their potential use as fusion reactor structural materials is the effect of simultaneous generation of helium and neutron damage: In the present Dynamic Helium Charging Experiment (DHCE), helium was produced uniformly in the specimen at linear rates of $\approx 0.4$ to 4.2 appm helium/dpa by the decay of tritium during irradiation to $18-31$ dpa at $425-600^{\circ} \mathrm{C}$ in Li-filled capsules in a sodium-cooled fast reactor. This paper presents results of postirradiation examination and tests of microstructure and mechanical properties of $\mathrm{V}-$ $5 \mathrm{Ti}, \mathrm{V}-3 \mathrm{Ti}-1 \mathrm{Si}, \mathrm{V}-8 \mathrm{Cr}-6 \mathrm{Ti}$, and $\mathrm{V}-4 \mathrm{Cr}-4 \mathrm{Ti}$ (the latter alloy has been identified as the most promising candidate vanadium alloy). Effects of helium on tensile strength and ductility were insignificant after irradiation and testing at $>420^{\circ} \mathrm{C}$. However, postirradiation ductilities at $<250^{\circ} \mathrm{C}$ were higher than those of the non-DHCE specimens $(<0.1$ appm helium), whereas strengths were lower, indicating that different types of hardening centers are produced during DHCE and non-DHCE irradiation. Ductile-brittle transition behavior of the DHCE specimens was also determined from bend tests and fracture appearance of transmission electron microscopy (TEM) disks and broken tensile specimens. No brittle behavior was observed at temperatures $>-150^{\circ} \mathrm{C}$ in $\mathrm{DHCE}$ specimens. Predominantly brittle-cleavage fracture morphologies were observed only at $-196^{\circ} \mathrm{C}$ in some specimens that were irradiated to $31 \mathrm{dpa}$ at $425^{\circ} \mathrm{C}$ during the DHCE. For the helium generation rates in this experiment $(\approx 0.4-4.2$ appm $\mathrm{He} / \mathrm{dpa})$, grain-boundary coalescence of helium microcavities was negligible and intergranular fracture was not observed.
\end{abstract}

\section{INTRODUCTION}

Vanadium-base alloys have significant advantages over other candidate alloys (such as austenitic and ferritic steels) for use as structural materials in fusion devices. These advantages include intrinsically lower levels of long-term activation, irradiation afterheat, neutron-induced helium- and hydrogen-transmutation rates, biological hazard potential, and thermal stress factor. Recent attention has focused on $\mathrm{V}$-4Cr-4Ti because of its excellent combination of mechanical and physical properties before and after irradiation [1-6] including virtual immunity to neutron displacement damage [2]. One property of vanadium-base alloys that is not well understood is the effect of helium; no data have been reported on effects of simultaneous generation of helium and neutron displacement damage under fusion-relevant conditions (i.e., $\approx 5 \mathrm{appm} \mathrm{He/dpa} \mathrm{ratio),} \mathrm{although} \mathrm{helium}$ effects on other vanadium alloys have been investigated by less-than-prototypical simulation techniques such as tritium-trick [7-11], cyclotron-injection [12-16], and borondoping [16-19]. In the Dynamic Helium Charging Experiment (DHCE) [20-22], the fusionrelevant helium-to-dpa damage ratio is simulated by utilizing slow transmutation of controlled amounts of $6 \mathrm{Li}$ and a tritium-doped mother vanadium immersed in ${ }^{6} \mathrm{Li}+{ }^{7} \mathrm{Li}$. This paper presents results of postirradiation examination of mechanical properties and microstructural characteristics of the reference alloy $\mathrm{V}-4 \mathrm{Cr}-4 \mathrm{Ti}$, as well as of unalloyed V, $\mathrm{V}-5 \mathrm{Ti}, \mathrm{V}-8 \mathrm{Cr}-6 \mathrm{Ti}$, and $\mathrm{V}-3 \mathrm{Ti}-1 \mathrm{Si}$.

\section{MATERIALS AND PROCEDURES}

The elemental composition of the alloys, determined prior to irradiation, is given in Table 1. Test specimens, machined from annealed plates and sheets to investigate tensile and swelling behaviors and microstructural characteristics, were fully recrystallized and exhibited an average grain size of $\approx 14-30 \mu \mathrm{m}$. The only secondary phase in the asannealed specimen was $\mathrm{Ti}(\mathrm{O}, \mathrm{N}, \mathrm{C})$, which is normally observed in titanium-containing vanadium alloys with $\mathrm{O}+\mathrm{N}+\mathrm{C}>400$ wppm. 
The alloy specimens were irradiated in the Fast Flux Test Facility (FFTF), a sodiumcooled fast reactor, at 420,520 , and $600^{\circ} \mathrm{C}$ to neutron fluences $(\mathrm{E}>0.1 \mathrm{MeV}$ ) ranging from $3.7 \times 10^{22} \mathrm{n} / \mathrm{cm}^{2}\left(\approx 18\right.$ displacements per atom, or dpa) to $6.4 \times 10^{23} \mathrm{n} / \mathrm{cm}^{2} \Leftrightarrow 31$ dpa). Helium in the alloy specimens was produced by utilizing transmutation of controlled amounts of ${ }^{6} \mathrm{Li}$ and predetermined amounts of tritium-doped vanadium mother vanadium immersed in ${ }^{6} \mathrm{Li}+{ }^{7} \mathrm{Li}[20-22]$. Table 2 summarizes actual postirradiation parameters determined from tensile and disk specimens of the $\mathrm{V}-4 \mathrm{Cr}-4 \mathrm{Ti}$ alloy, i.e., fast neutron fluence, dose, and helium and tritium contents measured shortly after the postirradiation tests. Helium and tritium contents were determined by mass spectrometry at Rockwell International Inc., Canoga Park, California.

Table 1. Chemical composition of alloys investigated

\begin{tabular}{cccrrr}
\hline Alloy & Nominal Composition & \multicolumn{4}{c}{ Impurity Composition (wppm) } \\
\cline { 3 - 6 } ANL ID & (wt.\%) & O & \multicolumn{1}{c}{ N } & \multicolumn{1}{c}{ C } & Si \\
\hline BL-19 & V & 1101 & 161 & 360 & - \\
BL-45 & V-2.5Ti-1Si & 345 & 125 & 90 & 9900 \\
BL-46 & V-4.6Ti & 305 & 53 & 85 & 160 \\
BL-47 & V-4.1Cr-4.3Ti & 350 & 220 & 200 & 870 \\
BL-49 & V-7.9Cr-5.7Ti & 400 & 150 & 127 & 360 \\
\hline
\end{tabular}

Table 2. Summary of irradiation parameters of Dynamic Helium Charging Experiment and helium and tritium contents measured in vanadium alloy specimens

\begin{tabular}{ccccccc}
\hline $\begin{array}{c}\text { Capsule } \\
\text { ID No. }\end{array}$ & $\begin{array}{c}\text { Irradiation } \\
\text { Temp. } \\
\left({ }^{\circ} \mathrm{C}\right)\end{array}$ & $\begin{array}{c}\text { Fluence } \\
(\mathrm{E}>0.1 \mathrm{MeV}) \\
\left(10^{22} \mathrm{n} \mathrm{cm}^{-2}\right.\end{array}$ & $\begin{array}{c}\text { Total } \\
\text { Damage } \\
\text { (dpa) }\end{array}$ & $\begin{array}{c}\text { Measured } \\
\text { Helium } \\
\text { Content } \\
\text { (appm) }\end{array}$ & $\begin{array}{c}\text { Actual } \\
\text { Helium to } \\
\text { dpa Ratio } \\
\text { (appm/dpa) }\end{array}$ & $\begin{array}{c}\text { Measured } \\
\text { Tritium } \\
\text { Content } \\
\text { (appm) }\end{array}$ \\
\hline 4D1 & 425 & 6.4 & 31 & $11.2-13.3$ & 0.39 & 27 \\
4D2 & 425 & 6.4 & 31 & $22.4-22.7$ & 0.73 & 39 \\
$5 \mathrm{E} 2$ & 425 & 3.7 & 18 & $3.3-3.7$ & 0.11 & 2 \\
$5 \mathrm{D} 1$ & 500 & 3.7 & 18 & $14.8-15.0$ & 0.83 & 4.5 \\
$5 \mathrm{E} 1$ & 500 & 3.7 & 18 & $6.4-6.5$ & 0.36 & 1.7 \\
$5 \mathrm{Cl}$ & 600 & 3.7 & 18 & $8.4-11.0$ & 0.54 & 20 \\
$5 \mathrm{C} 2$ & 600 & 3.7 & 18 & $74.9-75.3$ & 4.17 & 63 \\
\hline
\end{tabular}

Tensile properties were measured at $23^{\circ} \mathrm{C}, 100^{\circ} \mathrm{C}, 200^{\circ} \mathrm{C}$, and at irradiation temperatures in flowing argon at a strain rate of $0.0011 \mathrm{~s}^{-1}$. Fracture behavior was determined by repeatedly bending a TEM disk or a piece of broken tensile specimen until fracture in low-temperature baths of liquid nitrogen or mixtures of dry ice and acetone. Temperature of the surrounding liquid was measured with a calibrated thermocouple. After fracture, morphology of the fracture surface was examined quantitatively by SEM. Four types of fracture morphology were observed: cleavage, quasi-cleavage, ductile-dimple, and fibrous ductile fracture. From the fracture surface composite, the percentage of ductile-fracture morphology was measured for each specimen with a planimeter.

The irradiated TEM disks were jet-thinned in a solution of $15 \%$ sulfuric acid-72\% methanol-13\% butyl cellosolve maintained at $-5^{\circ} \mathrm{C}$. TEM was conducted with a JEOL $100 \mathrm{CX}-\mathrm{II}$ scanning transmission electron microscope (100 keV) or with a Philips CM-30 analytical electron microscope $(200 \mathrm{keV})$. Density change was determined from broken shoulders of tensile specimens by measuring weights in air and in research-grade $\mathrm{CCl}_{4}$.

\section{TENSILE PROPERTIES}

Yield strength, ultimate tensile strength, uniform elongation, and total elongation measured on tensile specimens of $\mathrm{V}-4 \mathrm{Cr}-4 \mathrm{Ti}$ irradiated at $425^{\circ} \mathrm{C}-600^{\circ} \mathrm{C}(18-31 \mathrm{dpa}, 4-75$ appm $\mathrm{He}$ ) are summarized in Figs. 1A-1D, respectively. In the figure, similar properties measured on specimens irradiated in non-DHCE have been also plotted as function of irradiation and tensile test temperature. Similar results of ultimate tensile strength and total elongation measured on tensile specimens of V-5Ti (9-20 appm He), V-3Ti-1Si (636 appm $\mathrm{He}$ ), and V-8Cr-6Ti (helium content unknown) are shown in Figs. 2-4. 

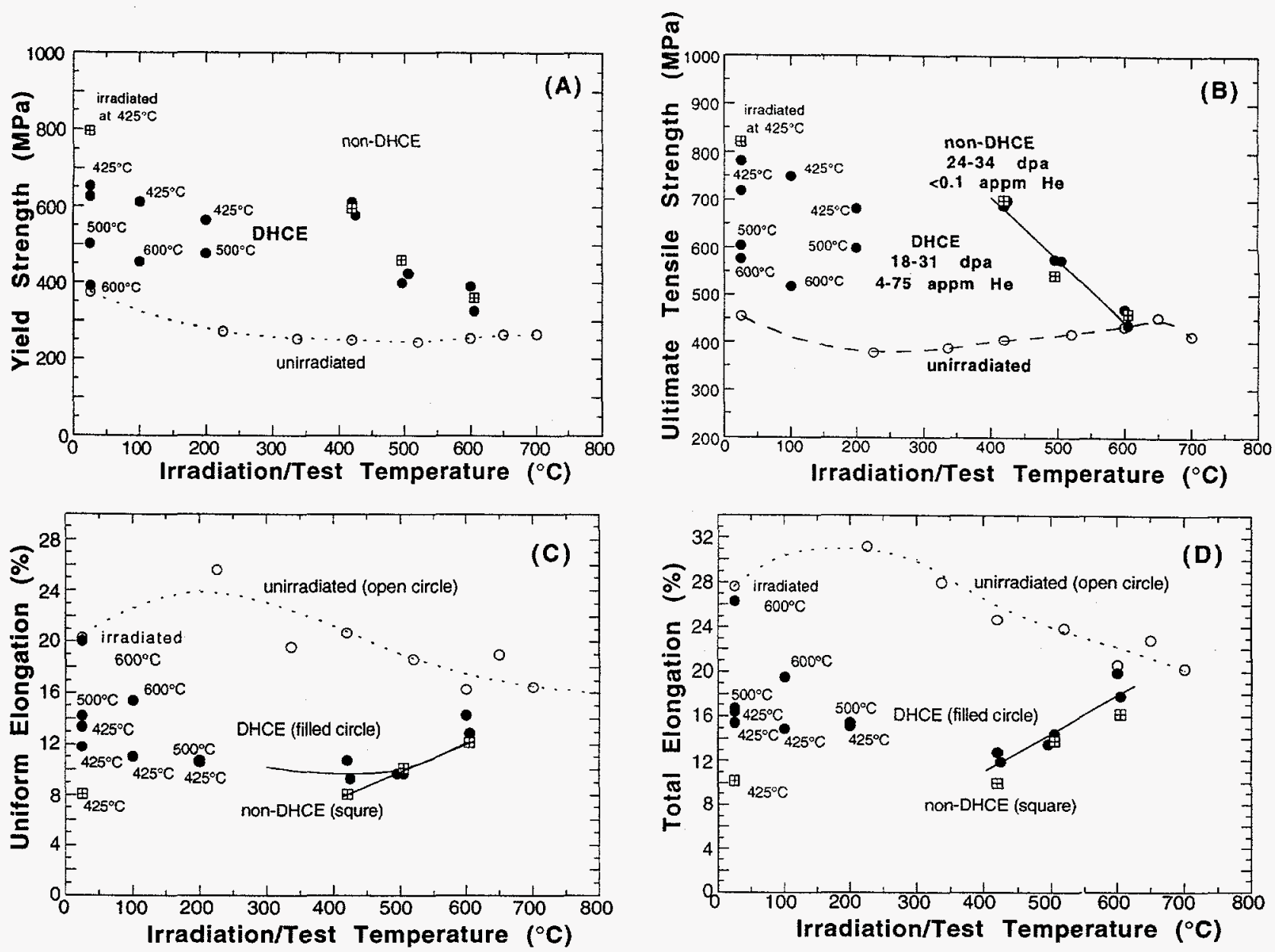

Fig. 1. Yield strength (A), ultimate tensile strength (B), uniform elongation (C), and total elongation (D) of $\mathrm{V}-4 \mathrm{Cr}-4 \mathrm{Ti}$ after irradiation at $420-600^{\circ} \mathrm{C}$ to $18-$ $31 \mathrm{dpa}$ in the DHCE (4-75 appm He) and in non-DHCE (<0.1 appm He).

After irradiation to $\approx 31 \mathrm{dpa}$ in either a DHCE or a non-DHCE, the four alloys retained significantly high ductilities, i.e., $>8 \%$ uniform elongation and $>10 \%$ total elongation. Although helium contents in the DHCE materials were relatively low, the dependence of uniform and total elongation on irradiation and test temperature, shown in Figs. 1-4, is in sharp contrast to similar results obtained on specimens in which helium atoms were produced by the tritium-trick method. In the latter type of experiments, total elongation measured at room temperature and at $700-800^{\circ} \mathrm{C}$ was significantly lower than that measured at $500-600^{\circ} \mathrm{C}$ because of strong susceptibility to intergranular cracking associated with extensive formation of grain-boundary helium microcavities [10]. However, no intergranular fracture surface morphology was observed in the present tensile specimens irradiated in the $\mathrm{DHCE}$ and tested at $23-600^{\circ} \mathrm{C}$. Tensile properties of the DHCE specimens measured at $400-600^{\circ} \mathrm{C}$ were essentially the same as those measured on non-DHCE specimens, showing that the effect of helium was insignificant. This is shown conveniently in Fig. 5, in which the ratio of total strain in specimens with and without helium is plotted as a function of irradiation and test temperature for the DHCE and tritium-trick experiments. In the tritium-trick experiments, deleterious effect of helium was significant (strain ratio $<1$, Fig. 5) for test temperatures of $25^{\circ} \mathrm{C}$ or $>650^{\circ} \mathrm{C}$. In contrast to this, deleterious effect of helium was not observed in DHCE (strain ratio $\geq 1$ ).

Interestingly, ductilities of the DHCE specimens of all the four alloys (irradiated at $\left.425-600^{\circ} \mathrm{C}\right)$ measured at $<250^{\circ} \mathrm{C}$ were higher than those of the similar non-DHCE specimens (i.e., strain ratio $>1$, Fig. 5), whereas strengths were lower. This indicates that a different type of hardening centers, stable at $<250^{\circ} \mathrm{C}$ and absent in non-DHCE specimens, were produced during DHCE. 



Fig. 2. Ultimate tensile strength (A) and total elongation (B) of V-5Ti after irradiation at $420-600^{\circ} \mathrm{C}$ to $18-31$ dpa in the DHCE (9-20 appm He) and in non-DHCE $(<0.1$ appm $\mathrm{He})$.
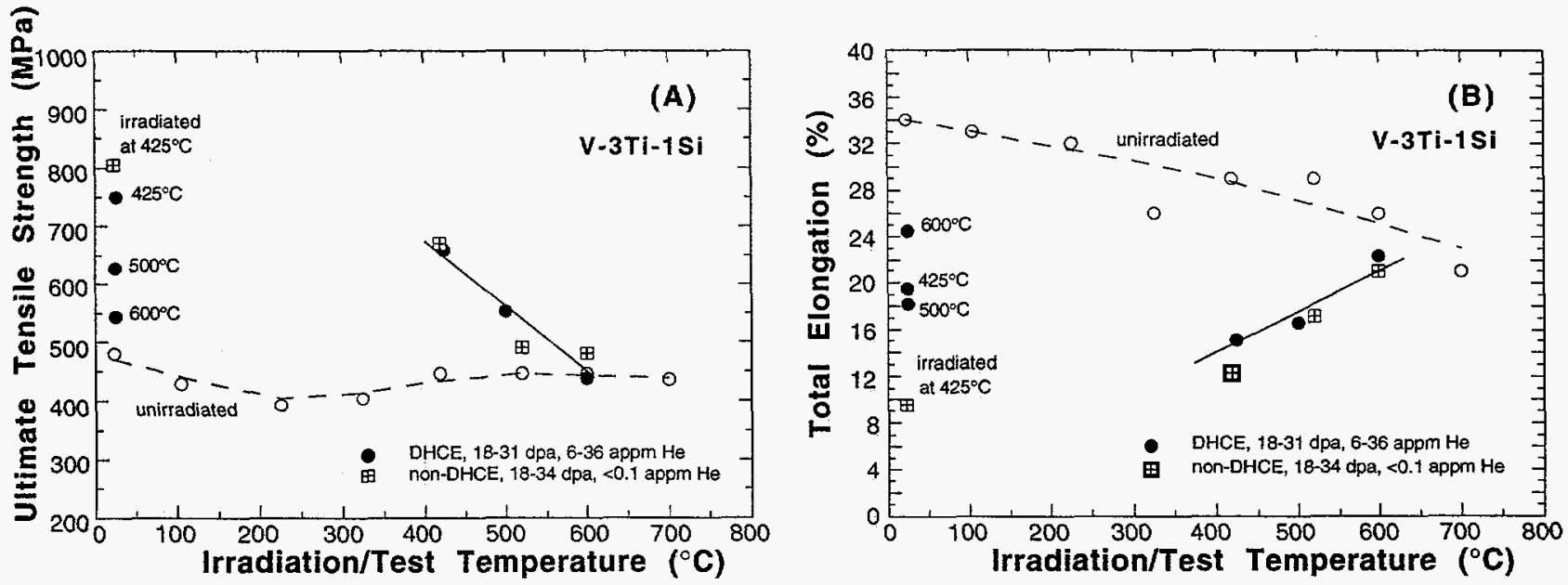

Fig. 3. Ultimate tensile strength (A) and total elongation (B) of V-3Ti-1Si after irradiation at $420-600^{\circ} \mathrm{C}$ to $18-31$ dpa in the DHCE (6-36 appm $\mathrm{He})$ and in non-DHCE (<0.1 appm He).
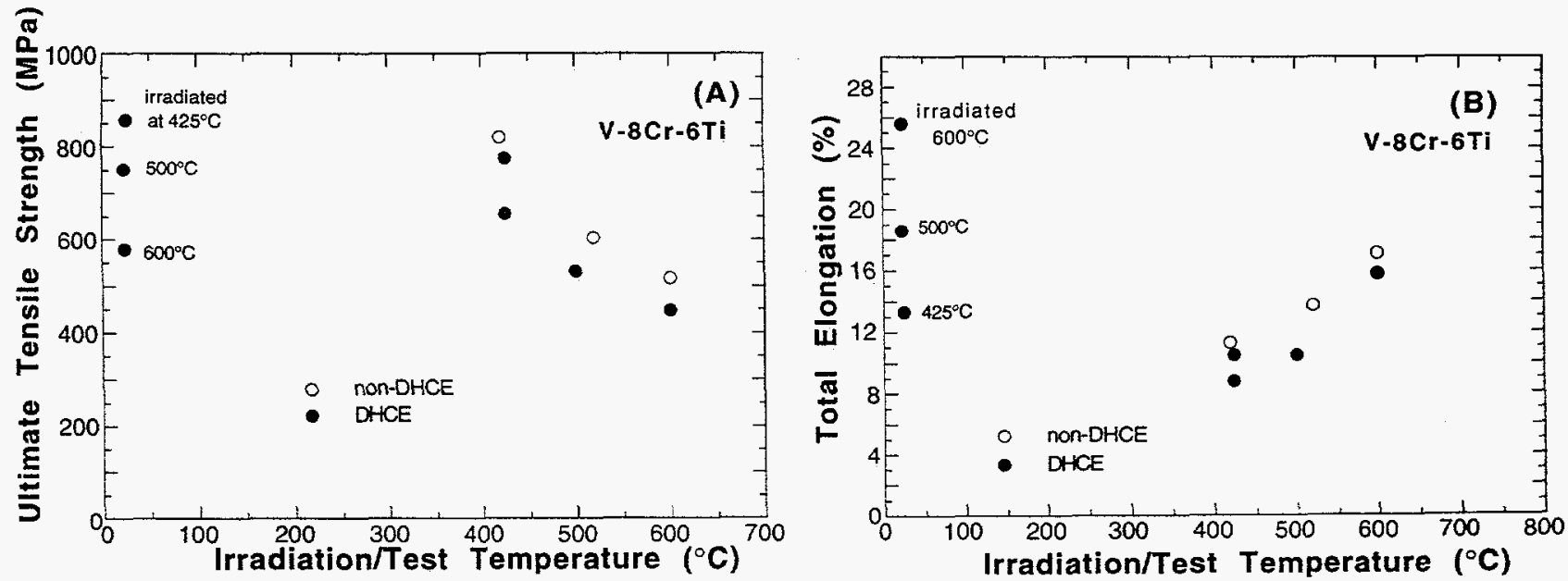

Fig. 4. Utimate tensile strength (A) and total elongation (B) of $\mathrm{V}-8 \mathrm{Cr}-6 \mathrm{Ti}$ after irradiation at $420-600^{\circ} \mathrm{C}$ to $18-31$ dpa in the DHCE (helium content unknown) and in non-DHCE. 


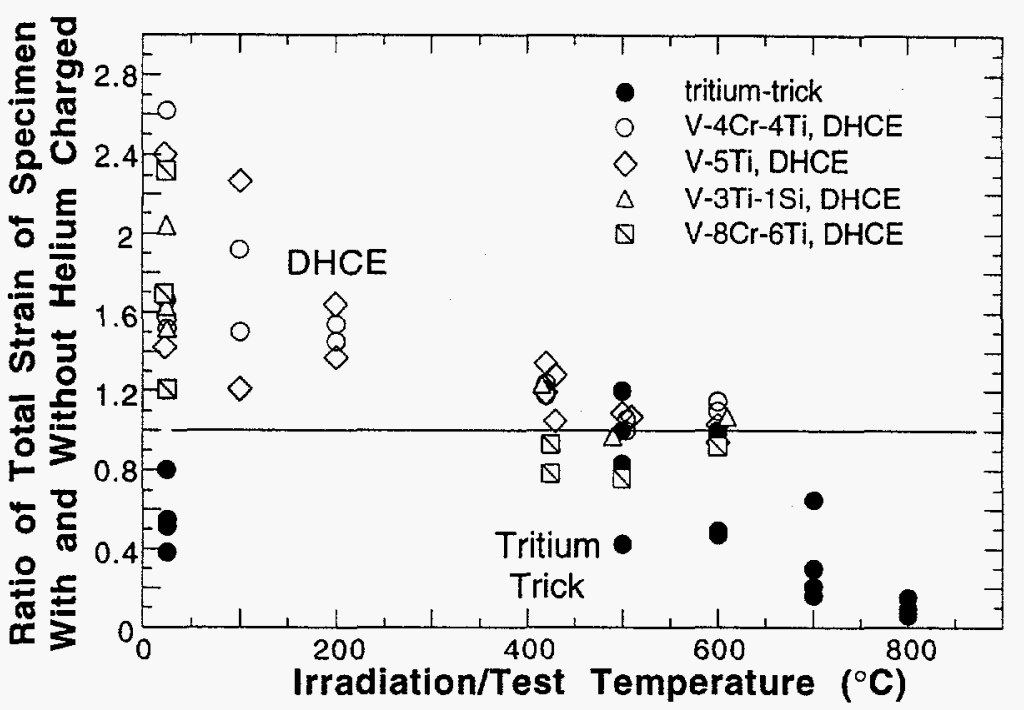

Fig. 5.

Ratio of total strain in specimens with and without helium as a function of irradiation and test temperature. Results obtained from tritium-trick experiment and DHCE are shown for comparison.

\section{DUCTILE-BRITTLE TRANSITION BEHAVIOR}

Fracture behavior of the reference alloy $\mathrm{V}-4 \mathrm{Cr}-4 \mathrm{Ti}$ was investigated by multiple-bend tests on irradiated miniature specimens. Because no Charpy-impact specimens were irradiated in the DHCE, a TEM disk $(0.3-\mathrm{mm}$ thick) or a broken piece (thickness 0.8 to $1.0 \mathrm{~mm}$ ) of a tensile specimen submerged in a low-temperature bath was bent repeatedly until fracture, and cleavage morphology was characterized quantitatively to determine ductile-brittle transition behavior. As reported previously, brittle fracture of $\mathrm{V}-4 \mathrm{Cr}-4 \mathrm{Ti}$ did not occur at temperatures $>-196^{\circ} \mathrm{C}$ in impact tests on one-third-size Charpy specimens either in the nonirradiated condition [5] or after irradiation to 24-34 dpa at $425-600^{\circ} \mathrm{C}$ in non-DHCE $(<0.1$ appm $\mathrm{He})[2]$.

The percentage of fracture surface of disk and broken tensile specimens of $\mathrm{V}-4 \mathrm{Cr}-4 \mathrm{Ti}$ (irradiated at $425-600^{\circ} \mathrm{C}, 18-31 \mathrm{dpa}, 4-75 \mathrm{appm} \mathrm{He}$ ) with ductile-fracture morphology is plotted as a function of test temperature in Figs. 6A and 6B. The figures show effects of simultaneous displacement damage, helium generation (at rates of $0.4-4.2$ appm helium/dpa), and tritium (2-63 appm) uptake on ductile-brittle transition behavior. For comparison, similar results obtained for nonirradiated and irradiated non-DHCE specimens (containing negligible amounts of helium, tritium, and hydrogen) are also shown. Despite the thickness difference, ductile-brittle transition behaviors of the disk and broken tensile specimens were similar.

The results in Fig. 6 show that the percentage of brittle cleavage measured from fracture surfaces produced near $-190^{\circ} \mathrm{C}$ was generally more pronounced in specimens irradiated at $425^{\circ} \mathrm{C}$. As in non-DHCE irradiation, no brittle behavior was observed at temperatures $>-150^{\circ} \mathrm{C}$ for DHCE specimens in which helium generation rate was $\approx 0.4-4.2$ appm helium/dpa. Predominantly brittle-cleavage fracture morphologies were observed only at $-196^{\circ} \mathrm{C}$ in some specimens irradiated to $31 \mathrm{dpa}$ at $425^{\circ} \mathrm{C}$ during DHCE. The results in Figs. 6 indicate that the DBTTs for specimens irradiated at $425^{\circ} \mathrm{C}$ and $500-600^{\circ} \mathrm{C}$ are -175 and $-200^{\circ} \mathrm{C}$, respectively. As in case of tensile tests at $25-600^{\circ} \mathrm{C}$, no intergranular fracture was observed in any specimens fractured at -196 to $50^{\circ} \mathrm{C}$ by multiple bending. However, these observations made on thin specimens should be interpreted with caution, and it is important to investigate fracture toughness and crack growth behavior of the alloys utilizing thicker compact-tension and impact specimens.

\section{MICROSTRUCTURE AND HELIUM BUBBLE DISTRIBUTION}

Voids or helium microcavities formed in the DHCE specimens were insignificant except for the unalloyed vanadium. For irradiations at $500-600^{\circ} \mathrm{C}$, only a few helium bubbles were observed on the Ti(O,N,C) precipitate interface in $\mathrm{V}-5 \mathrm{Ti}, \mathrm{V}-4 \mathrm{Cr}-4 \mathrm{Ti}, \mathrm{V}-8 \mathrm{Cr}-$ 6Ti, and V-3Ti-1Si; virtually all of the dynamically produced helium atoms in these alloys seem to have been trapped in the grain matrix without significant bubble nucleation. 

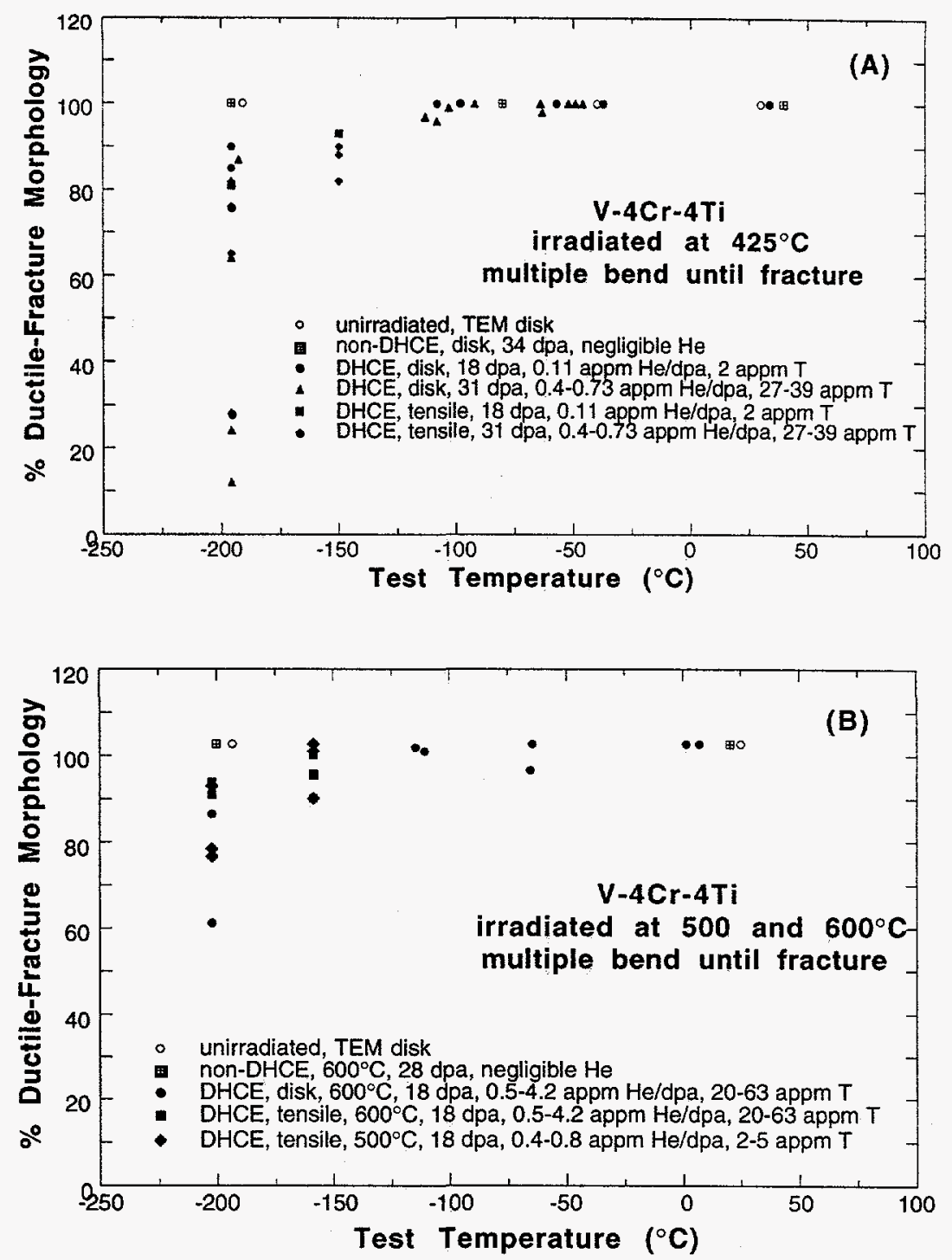

Fig. 6. Percent ductile-fracture morphology vs. test temperature of $V-4 C r-4 T i$ TEM disks and broken tensile specimens irradiated at (A) $425^{\circ} \mathrm{C}$ and $(B)$ $600^{\circ} \mathrm{C}$ and fractured by multiple bending.

For unalloyed vanadium specimens, in particular those irradiated to $\approx 31 \mathrm{dpa}$ at $425^{\circ} \mathrm{C}$, high-density helium bubbles $(\approx 10 \mathrm{~nm}$ in diameter) were observed in the grain matrix. However, as shown in Fig. 7A, no evidence of grain-boundary coalescence of helium bubbles was observed; in contrast to tritium-trick experiment, helium atoms produced dynamically in presence of displacement damages seem to form bubbles more or less uniformly within grain and on grain boundaries. Diffuse helium bubbles limited in number density within grains and on grain boundaries were observed in V-5Ti (9-20 appm He) and V-3Ti-1Si (6-36 appm He) irradiated at $425^{\circ} \mathrm{C}$ to $\approx 31$ dpa (Figs. $7 \mathrm{~B}$ and $7 \mathrm{C}$, respectively). However, in $\mathrm{V}-4 \mathrm{Cr}-4 \mathrm{Ti}$ specimens irradiated at $425^{\circ} \mathrm{C}$ to $\approx 31 \mathrm{dpa}(11-23$ appm He), only a limited number of helium bubbles were distributed more or less uniformly within grain and on grain boundaries; no evidence of grain-boundary coalescence was observed (Fig. 7D).

In the present DHCE, tritium-charged mother vanadium (unalloyed) was inserted in the capsule to generate helium in addition to the helium generation from transmutation of $6 \mathrm{Li}$. At the relatively low temperature of $=425^{\circ} \mathrm{C}$, these initially charged tritium atoms are likely to have been diffused in the early period of reactor startup to grain boundaries of the 

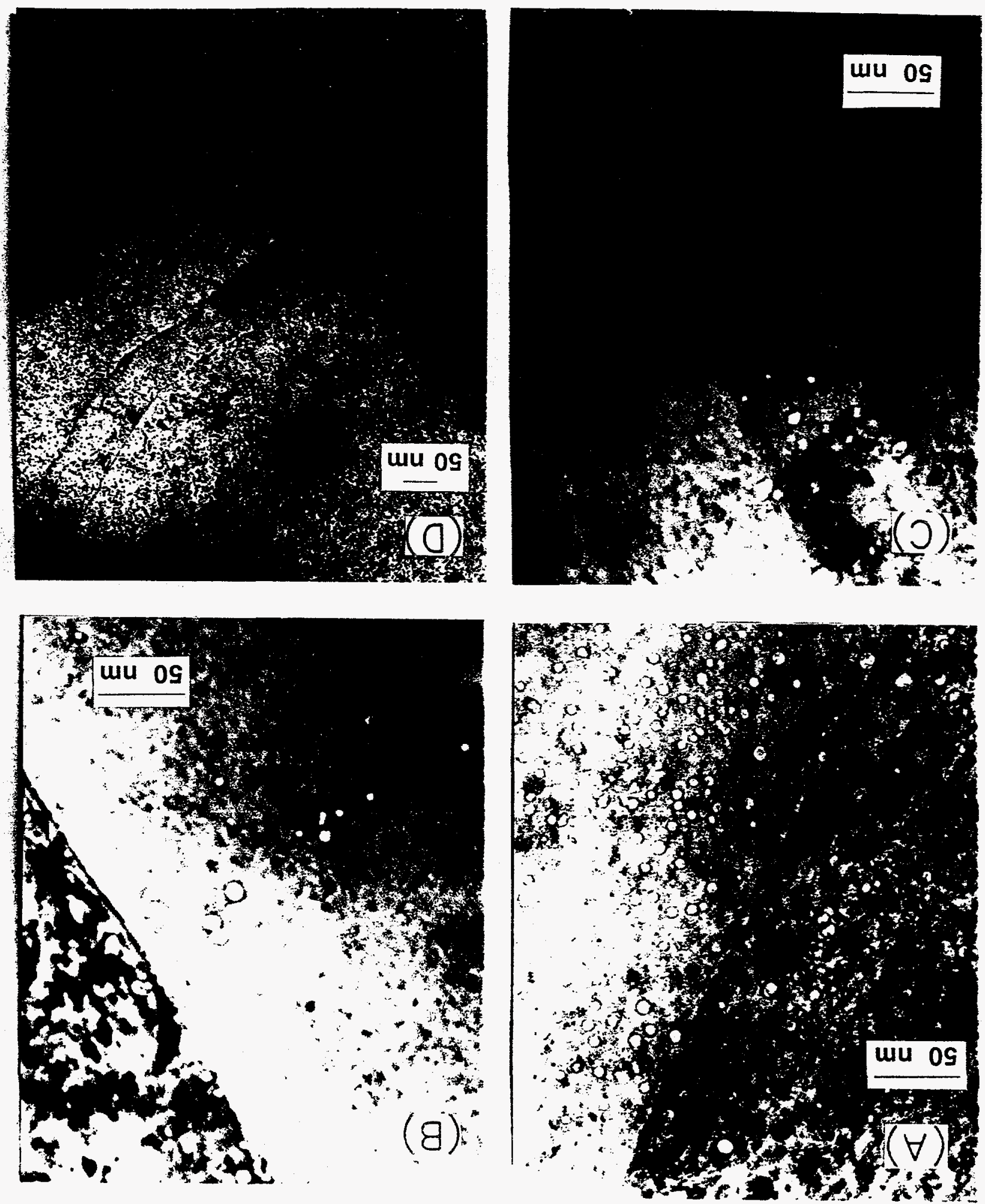
alloys in which dpa damage was still negligible. This in effect should have created a condition that is exactly parallel to "tritium trick" experiment in which tritiums are usually diffused at $\approx 400^{\circ} \mathrm{C}$ (in absence of dpa damage) and accumulate at grain boundaries. At higher temperatures $\left(>500^{\circ} \mathrm{C}\right)$, tritium atoms do not accumulate on grain boundaries. Therefore, in the present DHCE at $425^{\circ} \mathrm{C}$, significant helium could have been generated near grain boundaries of $\mathrm{V}-5 \mathrm{Ti}$ and $\mathrm{V}-3 \mathrm{Ti}-1 \mathrm{Si}$ from the tritium accumulated on the grain boundaries in the early period. That is, it is suspected that the present DHCE at $425^{\circ} \mathrm{C}$ did not truly simulate helium generation under the conditions of a fusion reactor, allowing in effect a "partial tritium-trick" condition in some alloys. This can be verified from a further investigation in which a higher concentration of ${ }^{6} \mathrm{Li}$ should be used at the expense of the tritium-charged mother vanadium.

\section{DENSITY CHANGE}

Density could be determined more accurately by measurements on broken tensile specimens $(80-120 \mathrm{mg})$ than on TEM disks $(\approx 10 \mathrm{mg})$. Results of density measurements (i.e., decrease in density) on pieces of tensile specimens of $\mathrm{V}-4 \mathrm{Cr}-4 \mathrm{Ti}, \mathrm{V}-5 \mathrm{Ti}, \mathrm{V}-3 \mathrm{Ti}-1 \mathrm{Si}$, and $\mathrm{V}-8 \mathrm{Cr}-6 \mathrm{Ti}$ are given in Figs. 8A-8D, respectively. For comparison, density changes determined for similar irradiation conditions in non-DHCEs [3] are also shown in the figures. Density changes measured for the non-DHCE and DHCE specimens were low $(<0.5 \%)$. The small density change seems to be consistent with the negligible number density of voids or helium bubbles. Density changes measured for the DHCE specimens irradiated at $425^{\circ} \mathrm{C}$ were somewhat higher than those for specimens irradiated at 500$600^{\circ} \mathrm{C}$. At least for helium generation rates in the range of $0.4-4.2$ appm $\mathrm{He} / \mathrm{dpa}$, there was no evidence of a significant effect of dynamically charged helium on density change; the reference alloy $\mathrm{V}-4 \mathrm{Cr}-4 \mathrm{Ti}$ seems to be inherently resistant to swelling under the present conditions of the DHCE and non-DHCE, indicating that swelling of the alloy under fusion reactor conditions would be also low.

\section{DISCUSSION}

An important finding from the DHCE was that the actual contents of helium and tritium in the $\mathrm{V}-4 \mathrm{Cr}-4 \mathrm{Ti}$ specimens were significantly lower than those calculated previously on the basis of assumed equilibrium ratio of tritium in the alloy to that in the liquid lithium. Except for specimens irradiated in Capsule $5 \mathrm{C} 1$ and $5 \mathrm{C} 2$ at $600^{\circ} \mathrm{C}$, actual helium/dpa ratios were several times lower than those calculated on the basis of an equilibrium ratio of 0.01 . This indicates that the level of hydrogen and tritium in the lithium-cooled V-4Cr-4Ti first wall/blanket structure, and hence the effect of hydrogen and tritium on fracture toughness, will be significantly lower than previously assumed.

Helium bubbles were negligible in all specimens except for those irradiated at $425^{\circ} \mathrm{C}$ and retrieved from Capsule $4 \mathrm{D} 1$ and $4 \mathrm{D} 2$. Even in specimens irradiated at $600^{\circ} \mathrm{C}$ at the highest helium generation rate of $\approx 4.2 \mathrm{appm}$ helium/dpa, no microvoids could be detected in either grain matrix or grain boundaries. For specimens irradiated to $31 \mathrm{dpa}$ at $425^{\circ} \mathrm{C}$, moderate number densities of diffuse helium bubbles were observed in localized grain matrices and near a limited fraction of grain boundaries. The absence of intergranular fracture morphology in any of the specimens irradiated in the present DHCE seems to be consistent with the microstructural characteristics described above. However, despite the absence of intergranular fracture morphology in specimens irradiated at $600^{\circ} \mathrm{C}$ at a helium generation rate of $\approx 4.2 \mathrm{appm} / \mathrm{dpa}$, a more comprehensive data base is needed for irradiation temperatures $<450^{\circ} \mathrm{C}$ to determine the effects of higher helium-dpa ratio.

The uniform and total elongations determined from the room-temperature tensile tests on DHCE specimens were significantly greater than similar room-temperature elongations measured on specimens irradiated in either non-DHCE or tritium-trick experiments. This is also consistent with the absence of continuous aggregation of helium bubbles on grain boundaries in the specimens irradiated in DHCE. In addition, the observation indicates also that different types of hardening centers are produced in the alloy during DHCE (significant helium generation) and non-DHCE irradiation (negligible helium generation) at $425-600^{\circ} \mathrm{C}$. Although the nature of the hardening centers produced during DHCE is not understood at this time, helium atoms are believed to be associated with them. 

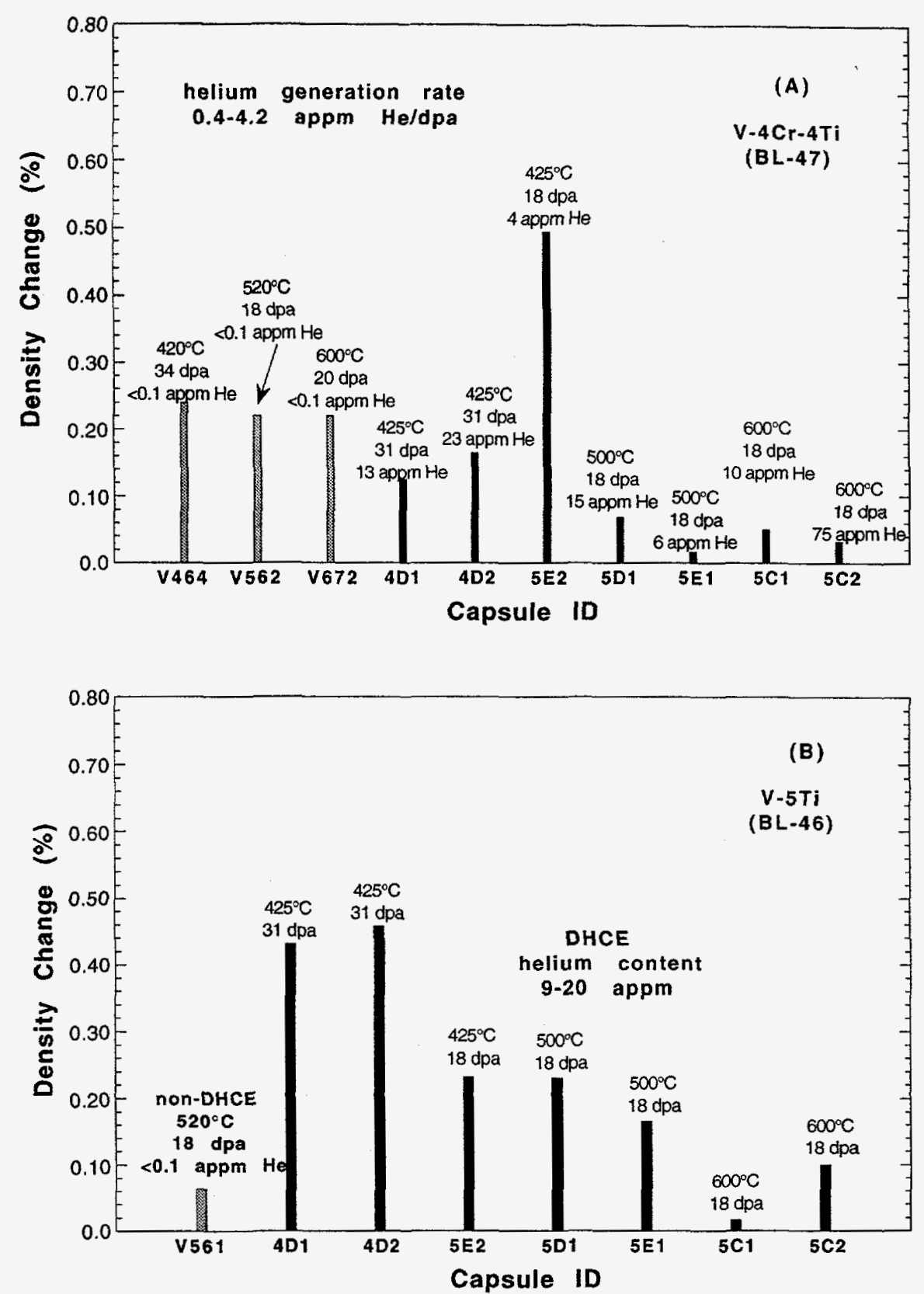

Fig. 8. Density decrease of (A) V-4Cr-4Ti, (B) V-5Ti, (C) V-3Ti-1Si, and (D) V-8Cr-6Ti after irradiation to 18-34 dpa at 420$600^{\circ} \mathrm{C}$ in the DHCE (dark bars) and in a non-DHCE (negligible helium) (light bars). Each bar represents the average of densities measured on three separate pieces of tensile specimens.

In a series of studies on thermal desorption behavior of helium from unalloyed vanadium and $\mathrm{V}-5 \mathrm{Ti}$ irradiated with helium ions of various energy levels, van Veen et al. $[23,24]$ concluded that helium-vacancy- $(\mathrm{O}, \mathrm{N}, \mathrm{C})$ complexes formed in the irradiated material. They further deduced that these complexes are stable at low temperatures $\left(<250^{\circ} \mathrm{C}\right)$ but dissociate into helium atoms and $\mathrm{O}$-vacancy and $\mathrm{N}$-vacancy complexes at temperatures higher than $=270^{\circ} \mathrm{C}$. Van Veen et al. deduced that this lead to the prominent helium desorption peak at $\approx 290^{\circ} \mathrm{C}$ that had been observed consistently in their experiments. Desorption peaks at $\approx 770^{\circ} \mathrm{C}$ and $\approx 1250^{\circ} \mathrm{C}$ were observed only after 
irradiation with helium ion to higher doses. These high-temperature desorption peaks were attributed to clusters of helium atoms and helium bubbles, respectively. The clusters and bubbles of helium are believed to be unstable only at the high temperatures.

Based on these observations, it is likely that stable helium-vacancy- $(O, N, C)$ complexes are also present in the specimens irradiated in DHCE during tensile tests at room temperature. In contrast, in specimens irradiated in non-DHCE under similar conditions, vacancies and impurities (such as $\mathrm{O}, \mathrm{N}$, and $\mathrm{C}$ ) are not expected to form complexes in the absence of appreciable helium atoms. Rather, the impurity atoms in solution and vacancies or vacancy clusters will be scattered more or less randomly in interstitial and vacancy sites, respectively. Dislocation motion would be more difficult under this condition, and hence ductility would be lower in the non-DHCE than in the DHCE specimens; this is in accordance with the results shown in Figs. 1-5.
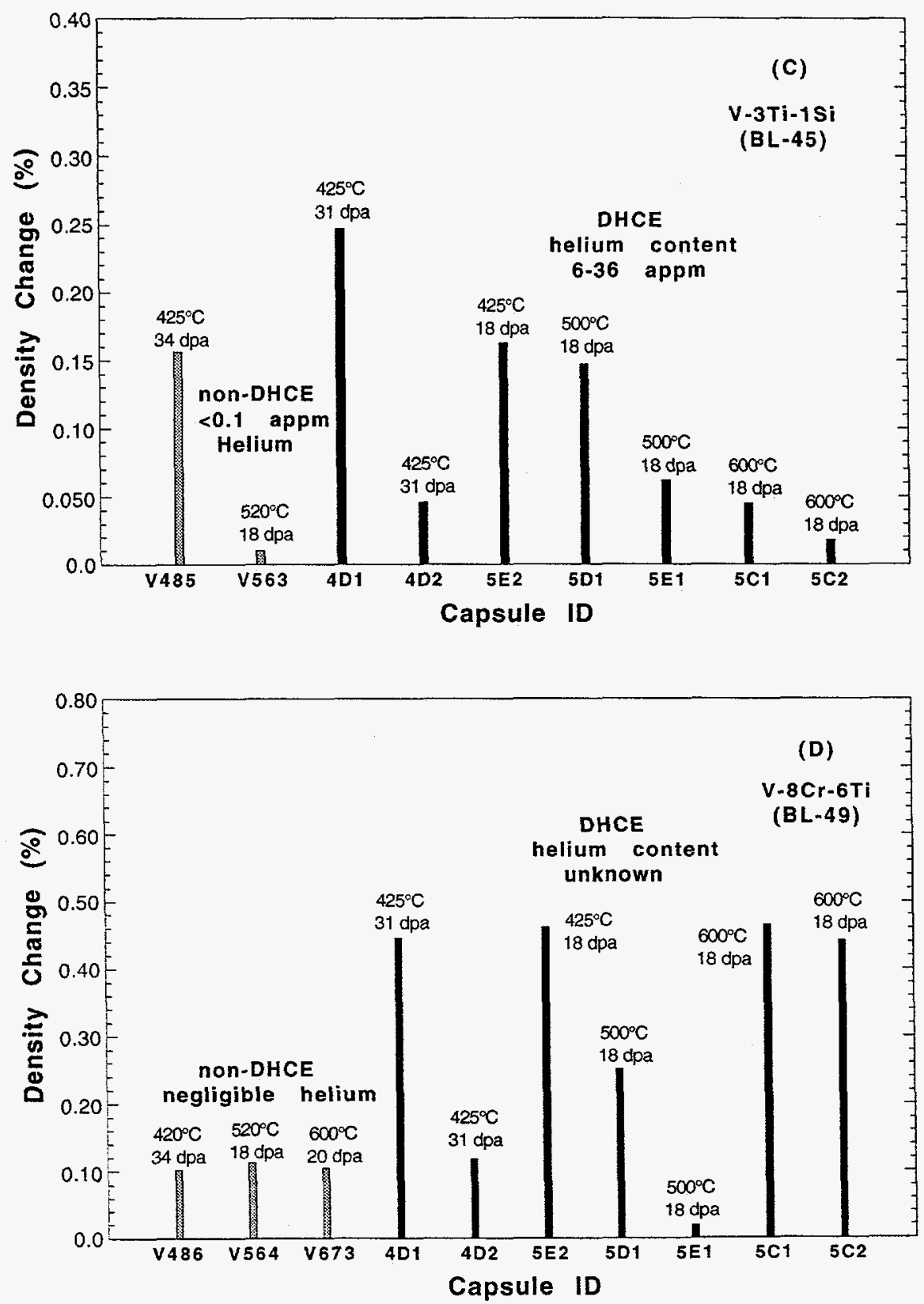

Fig. 8, Continued. 


\section{CONCLUSIONS}

1. Effects of dynamically charged helium, neutron damage, and retained tritium on ductile-brittle transition temperature (DBTT) of the reference alloy $\mathrm{V}-4 \mathrm{Cr}-4 \mathrm{Ti}$ were determined after irradiation in the Dynamic Helium Charging Experiment (DHCE). TEM disks and broken pieces of tensile specimens, irradiated at $425-600^{\circ} \mathrm{C}$ to $18-31$ $\mathrm{dpa}$ and at helium generation rates of $0.4-4.2 \mathrm{appm}$ helium/dpa, were fractured by repeated bending. DBTTs based on fracture appearance were -150 to $-200^{\circ} \mathrm{C}$ in these specimens.

2. Tensile ductilities of $\mathrm{V}-4 \mathrm{Cr}-4 \mathrm{Ti}, \mathrm{V}-5 \mathrm{Ti}, \mathrm{V}-3 \mathrm{Ti}-1 \mathrm{Si}$, and $\mathrm{V}-8 \mathrm{Cr}-6 \mathrm{Ti}$ remained significantly high at $25-600^{\circ} \mathrm{C}(>8 \%$ uniform elongation and $>10 \%$ total elongation). Tensile properties measured at $400-600^{\circ} \mathrm{C}$ were essentially the same as those measured on non-DHCE specimens (negligible helium), showing that effects of helium (helium generation rate $0.4-4.2 \mathrm{appm} \mathrm{He} / \mathrm{dpa}$ ) were insignificant. Ductilities at $<250^{\circ} \mathrm{C}$ of the DHCE specimens (irradiated at 425,500 , and $600^{\circ} \mathrm{C}$ ) were higher than those of the similar non-DHCE specimens, whereas strengths were lower. These observations indicate that different types of hardening centers are present at $<250^{\circ} \mathrm{C}$ in the $\mathrm{DHCE}$ specimens (helium-vacancy-impurities complex, the impurities being oxygen, nitrogen, and carbon) and in non-DHCE specimens (defects and defect clusters, impurities in interstitial sites).

3. In contrast to tritium-trick experiments, no evidence of grain-boundary coalescence of helium bubbles was observed in the present DHCE either in unalloyed vanadium or the reference alloy $\mathrm{V}-4 \mathrm{Cr}-4 \mathrm{Ti}$. Most of the helium atoms produced dynamically seem to be trapped in the grain matrix, preventing coalescence of helium bubbles on grain boundaries. Except for unalloyed vanadium, void swelling in the Ti-containing alloys was negligible.

4. No intergranular fracture was observed during tensile test at $23-600^{\circ} \mathrm{C}$ or bending test at $-196^{\circ} \mathrm{C}$ to $50^{\circ} \mathrm{C}$. This observation, consistent with the characteristic helium bubble distribution, is in distinct contrast to the propensity for intergranular fracture commonly observed in tritium-trick experiments.

5. Density changes of $\mathrm{V}-4 \mathrm{Cr}-4 \mathrm{Ti}, \mathrm{V}-5 \mathrm{Ti}, \mathrm{V}-3 \mathrm{Ti}-1 \mathrm{Si}$, and $\mathrm{V}-8 \mathrm{Cr}-6 \mathrm{Ti}$ irradiated to $18-31$ dpa at helium generation rates of $\approx 0.4$ to $\approx 4.2$ appm He/dpa were $<0.5 \%$.

6. The measured contents of helium and tritium in the $\mathrm{V}-4 \mathrm{Cr}-4 \mathrm{Ti}$ specimens indicate that the equilibrium ratio of tritium (in the alloy to that in the liquid lithium) is significantly lower than that assumed previously $(\approx 0.01$ by weight). This indicates that the level of tritium and hydrogen in the lithium-cooled V-4Cr-4Ti first wall/blanket structure, and hence the effect of tritium and hydrogen on fracture toughness, will be significantly lower than previously assumed.

\section{ACKNOWLEDGMENTS}

Successful completion of the Dynamic Helium Charging Experiment, a complex and difficult irradiation test, was possible only through many years of effort and contributions from many investigators in the United States and Japan: F. W. Wiffen, H. Matsui, K. Abe, C. E. Johnson, R. G. Clemmer, J. P. Kopasz, L. R. Greenwood, M. L. Hamilton, K. L. Pearce, R. Ermi, and A. Ermi. The authors are grateful to H.-C. Tsai and B. M. Oliver for retrieval of specimens and helium measurement, respectively. The authors also thank L. J. Nowicki, T. M. Galvin, D. E. Busch, J. Gazda, and K. Fukumoto for postirradiation examination and testing.

\section{REFERENCES}

[1] B. A. Loomis, L. Nowicki, and D. L. Smith, J. Nucl. Mater. 212-215 (1994), 790.

[2] B. A. Loomis, H. M. Chung, L. Nowicki, and D. L. Smith, J. Nucl. Mater. 212-215 (1994), 799.

[3] H. M. Chung, B. A. Loomis, and D. L. Smith, J. Nucl. Mater. 212-215 (1994), 804.

[4] H. Matsui, M. Tanno, J. Gazda, and H. M. Chung, in Fusion Reactor Materials, Semiannual. Prog. Report, DOE/ER-0313/15, Oak Ridge National Laboratory, Oak 
Ridge, TN (1994), pp. 240-246.

[5] H. M. Chung, B. A. Loomis, and D. L. Smith, Fusion Eng. Design 29 (1995), 455-464.

[6] H. M. Chung, B. A. Loomis, and D. L. Smith, J. Nucl. Mater. 212-215 (1994), 772.

[7] D. N. Braski, in Influence of Radiation on Material Properties, ASTM-STP 956 (1986), pp. 271-290.

[8] D. N. Braski, J. Nucl. Mater. 141-143 (1986) 1125.

[9] D. N. Braski, in Reduced Activation Materials for Fusion Reactors, ASTM-STP 1047 (1988), pp. 161-178.

[10] H. Matsui, M. Tanaka, M. Yamamoto, and M. Tada, J. Nucl. Mater. 191-194 (1992) 919.

[11] M. Satou, K. Abe, and H. Matsui, J. Nucl. Mater. 191-194 (1992) 938.

[12] W. van Witzenburg, A. Mastenbroek, and J. D. Ellen, J. Nucl. Mater. 103-104 (1981) 1187.

[13] M. P. Tanaka, E. E. Bloom, and J. A. Horak, J. Nucl. Mater. 114 (1981) 895.

[14] M. L. Grossbeck and J. A. Horak, in Influence of Radiation on Material Properties, ASTM-STP 956 (1986), p. 291.

[15] J. M. Vitek, D. N. Braski, and J. A. Horak, J. Nucl. Mater. 141-143 (1986) 982.

[16] W. van Witzenburg and E. de Vries, in Effects of Radiation on Materials. ASTM-STP 1125 (1990).

[17] L. L. Horton and K. Farrell, J. Nucl. Mater. 122-123 (1984) 687.

[18] H. Kawanishi and S. Ishino, in Reduced Activation Materials for Fusion Reactors, ASTM-STP 1047 (1988), pp. 179-189.

[19] H. Kawanishi, Y. Arai, and S. Ishino, J. Nucl. Mater. 191-194 (1992) 933.

[20] D. L. Smith, H. Matsui, L. R. Greenwood, and B. A. Loomis, J. Nucl. Mater. 155-157 (1988) 1359.

[21] D. L. Smith, B. A. Loomis, H. Matsui, M. L. Hamilton, K. L. Pearce, J. P. Kopasz, C. E. Johnson, R. G. Clemmer, and L. R. Greenwood, in Fusion Reactor Materials, Semiannual. Prog. Rep. DOE/ER-0313/10, Oak Ridge National Laboratory, Oak Ridge, TN (1991), p. 159.

[22] H. Tsai, H. M. Chung, B. A. Loomis, and D. L. Smith, in Fusion Reactor Materials. Semiannual. Prog. Report, DOE/ER-0313/15, Oak Ridge National Laboratory, Oak Ridge, TN (1994), pp. 247-252.

[23] A. van Veen, H. Eleveld, and M. Clement, J. Nucl. Mater. 212-215 (1994), 287.

[24] T. Buitenhuis, A. Fedorov, and A. van Veen, "Thermal Desorption Investigation of V-5Ti Alloy," IRI-131-94-005, Delft University of Technology, The Netherlands, 1994.

\section{DISCLAIMER}

This report was prepared as an account of work sponsored by an agency of the United States Government. Neither the United States Government nor any agency thereof, nor any of their employees, makes any warranty, express or implied, or assumes any legal liability or responsibility for the accuracy, completeness, or usefulness of any information, apparatus, product, or process disclosed, or represents that its use would not infringe privately owned rights. Reference herein to any specific commercial product, process, or service by trade name, trademark, manufacturer, or otherwise does not necessarily constitute or imply its endorsement, recommendation, or favoring by the United States Government or any agency thereof. The views and opinions of authors expressed herein do not necessarily state or reflect those of the United States Government or any agency thereof. 